\title{
ORIENTASI PEMBACA DALAM NOVEL "SUNSET BERSAMA ROSIE" KARYA TERE LIYE: ANALISIS RESEPSI SASTRA
}

\author{
Imas Juidah \\ e-mail: imasjuidah89@gmail.com
}

\begin{abstract}
ABSTRAK
Penelitian ini bertujuan untuk mendeskripsikan: (1) antisipasi dan retrospeksi, (2) kesan keserupaan dalam kehidupan, (3) respon personal terhadap novel "Sunset Bersama Rosie" karya Tere Liye. Untuk mencapai tujuan itu, dilakukan penelitian kualitatif deskriptif karena proses pelaksanaannya dilakukan untuk mendeskripsikan dan menginterpretasikan respon atau tanggapan pembaca terhadap novel "Sunset Bersama Rosie" karya Tere Liye. Data dalam penelitian ini adalah kutipan-kutipan kalimat yang terdapat dalam novel "Sunset Bersama Rosie". Sedangkan, sumber data dalam penelitian ini adalah novel "Sunset Bersama Rosie" karya Tere Liye yang diterbitkan oleh Mahaka Publishing pada tahun 2011 sebanyak 426 lembar. Teknik pengumpulan data yang digunakan dalam penelitian ini adalah analisis dokumen. Berdasarkan hasil dan pembahasan mengenai antisipasi dan retrospeksi, keserupaan dalam kehidupan dan respon personal dalam novel "Sunset Bersama Rosie" karya Tere Liye dapat disimpulkan bahwa sebagian pembaca ada yang merespon secara positif dan ada juga sebagian orang lain yang merespon secara negatif. Hal tersebut disebabkan oleh perbedaan cakrawala harapan setiap pembaca, karena masing-masing pembaca mempunyai pengalaman, pengetahuan yang berbeda-beda. Namun, secara keseluruhan novel "Sunset Bersama Rosie" karya Tere Liye masih relevan dengan realitas kehidupan masyarakat di Indonesia.
\end{abstract}

\section{Kata kunci: Orientasi Pembaca, Novel, Sunset Bersama Rosie, Resepsi Sastra.}

\section{A. PENDAHULUAN}

Karya sastra merupakan hasil cipta, rasa, dan karsa manusia yang mengandung daya imajinasi dengan menggunakan media bahasa dalam penyampaiannya. Karya sastra harus dipahami dan dinikmati berdasarkan konvensi sastra, sebab karya sastra merupakan dunia rekaan yang tercipta melalui proses penghayatan, pemikiran dan penilaian. Karya sastra lahir sebagai hasil perpaduan antara fenomena dunia nyata dan imajinasi pengarang serta refleksinya terhadap gejala-gejala sosial di sekitarnya. Dengan kata lain, tokoh-tokoh yang terdapat dalam karya sastra merupakan potret kehidupan yang terdapat dalam dunia nyata. Adapun manfaat sastra pada dasarnya adalah sebagai alat komunikasi antara sastrawan dan masyarakat pembacanya. Karya sastra dengan demikian selalu berisi pemikiran, gagasan, kisah-kisah dan amanat yang ingin disampaikan kepada para pembaca.

Pembaca sangat berperan penting dalam menentukan sebuah karya itu merupakan karya sastra atau bukan. Dalam teori estetika resepsi yang menjadi perhatian utama adalah pembaca karya sastra di antara jalinan segetiga pengarang, karya sastra, dan masyarakat pembaca (Jauss dalam Pradopo, 2002:23). Pembaca juga sangat erat hubungannya dengan karya sastra karena sadar atau tidak, sengaja atau tidak, akhirnya karya sastra akan sampai juga kepada pembaca, ditunjukkan kepada pembaca, bagi kepentingan masyarakat pembaca. Di samping itu, pembacalah yang menentukan makna dan nilai karya sastra. Karya sastra itu 
tidak mempunyai arti tanpa ada pembaca yang menanggapinya. Karya sastra itu mempunyai nilai karena ada pembaca yang menilai (Pradopo, 2011:207). Sebagai sebuah keutuhan komunikasi sastrawankarya sastra-pembaca, maka pada hakikatnya karya yang tidak sampai ke tangan pembacanya, bukanlah karya sastra. Karya sastra tidak mempunyai keberadaan nyata sampai karya sastra itu dibaca. Pembacalah yang menerapkan kode yang ditulis sastrawan untuk menyampaikan pesan (Selden dalam Siswanto, 2008:190). Menurut Abrams kajian yang menitikberatkan kajiannya terhadap peranan pembaca dalam menerima, memahami, dan menghayati karya sastra disebut pendekatan pragmatik atau yang lebih dikenal dengan istilah orientasi pembaca atau resepsi sastra.

Resepsi sastra adalah kajian yang mempelajari bagaimana pembaca memberikan makna terhadap karya sastra yang dibacanya sehingga dapat memberikan reaksi atau tanggapan terhadapnya, baik tanggapan pasif, maupun aktif (Junus dalam Siswanto, 2008:191). Reaksi atau tanggapan tersebut disebabkan karena karya sastra selalu bersifat evokatif, yaitu merangsang timbulnya perasaan dan imaji tertentu dalam diri seorang penikmatnya. Seorang seorang penikmat karya sastra tidak menghadapi karya sastra tersebut secara dingin, melainkan dengan suatu subjektivitas yang menggerakkannya untuk mengambil sikap terhadap karya sastra dengan menyetujui atau menolaknya, menyukai atau mencampakkannya (Kleden, 2004:9). Dengan demikian, pentingnya peranan pembaca dalam memberikan arti terhadap karya sastra dapat dilihat pada kenyataan bahwa seseorang dengan orang yang lain akan berbeda dalam menanggapi sebuah karya sastra.

Berbicara mengenai karya sastra, maka tidak lepas dari karya sastra yang disebut dengan novel. Novel merupakan salah satu jenis karya sastra yang sangat menarik untuk dikaji. Hal tersebut karena di dalam novel menyajikan cerita fiksi dalam bentuk tulisan atau kata-kata yang mempunyai unsur intrinsik dan ekstrinsik. Sebuah novel biasanya menceritakan tentang kehidupan manusia dengan bermacammacam masalah dalam interaksinya dengan lingkungan dan sesamanya. Seorang pengarang berusaha semaksimal mungkin mengarahkan pembaca kepada gambarangambaranrealita kehidupan lewat cerita yang ada dalam novel tersebut. Seperti halnya cerita yang ada dalam novel Sunset Bersama Rosie karya Tere Liye.

Tere Liye bagi sebagian orang mungkin masih merasa asing dengan nama ini. Namun, sebagian yang sudah membaca karyanya, dapat dipastikan tidak akan pernah ingin melewatkan karya selanjutnya. Nama Tere Liye sebenarnya bukan nama baru dijajaran nama-nama penulis di Indonesia. Karyanya pun tidak bisa dibilang kacangan. Sedikitnya, sudah 20 karya Tere Liye yang dibukukan oleh penerbit besar seperti Republika dan Gramedia. Karya tersebut antara lain Bumi, Bulan, Amelia, Eliana, Pukat, Burlian, Hafalan Shalat Delisa, Bidadari-bidadari Surga, Moga Bunda Disayang Allah, Rembulan Tenggelam di Wajahmu, Kisah Sang Penandai, Berjuta Rasanya, Sepotong Hati yang Baru, Ayahku (Bukan) Pembohong, Kau Aku dan Sepucuk Angpau Merah, Daun yang Jatuh Tak Pernah Membenci Angin, Negeri Para Bedebah, Negeri di Ujung Tanduk, Rindu, dan Sunset Bersama Rosie.

\section{Novel Sunset Bersama Rosie} merupakan salah satu novel karya Tere Liye yang menarik untuk dikaji berdasarkan pendekatan orientasi pembaca karena dalam novel ini menghadirkan tokoh-tokoh dengan karakter, kepribadian, dan emosi yang mungkin jarang kita jumpai di zaman sekarang sehingga sangat menarik untuk dikaji lebih dalam. Selain itu, ciri khas penulis bernama asli Darwis ini selalu mengangkat hal-hal sederhana namun sarat pesan dan makna yang mampu menggugah hati pembacanya. Bahkan, tak jarang 
menguras air mata. Dengan demikian, dalam tulisan ini akan mengungkapkan respon atau tanggapan pembaca terhadap novel Sunset Bersama Rosie, baik tanggapan pasif maupun tanggapan aktif.

\section{B. METODE}

Penelitian ini merupakan jenis penelitian kualitatif deskriptif karena proses pelaksanaannya dilakukan untuk mendeskripsikan dan menginterpretasikan respon atau tanggapan pembaca terhadap novel "Sunset Bersama Rosie" karya Tere Liye. Data dalam penelitian ini adalah kutipan-kutipan kalimat yang terdapat dalam novel "Sunset Bersama Rosie". Sedangkan, sumber data dalam penelitian ini adalah novel "Sunset Bersama Rosie" karya Tere Liye yang diterbitkan oleh Mahaka Publishing pada tahun 2011 sebanyak 426 lembar.

Teknik pengumpulan data yang digunakan dalam penelitian ini adalah analisis dokumen (content analysis). Langkah-langkah pengumpulan data yang dilakukan adalah sebagau berikut: 1) membaca secara intensif novel "Sunset Bersama Rosie" karya Tere Liye; 2) mengidentifikasi dan mencatat kutipankutipan kalimat percakapan yang ada dalam novel tersebut; 3) mengklasifikasikan data yang sudah diidentifikasi dalam kelompok antisipasi dan retrospeksi, keserupaan dalam kehidupan dan respon personal.

\section{HASIL PENELITIAN DAN PEMBAHASAN}

Orientasi pembaca terhadap isi novel "Sunset Bersama Rosie" mencakup tiga hal penting yaitu, antisipasi dan retrospeksi, keserupaan dalam kehidupan dan respon personal.

\section{Sinopsis}

Sebenarnya, apakah itu perasaan? Keinginan? Rasa memiliki? Rasa sakit, gelisah, sesak, tidak bisa tidur, kerinduan, kebencian? Bukankah dengan berlalunya waktu semuanya seperti gelas kosong yang berdebu, begitu-begitu saja, tidak istimewa. Malah lucu serta gemas saat dikenang. Sebenarnya, apakah pengorbanan memiliki harga dan batasan? Atau priceless, tidak terbeli dengan uang, karena hanya kita lakukan untuk sesuatu yang amat spesial di waktu yang juga spesial? Atau boleh jadi gratis, karena kita lakukan saja, dan selalu menyenangkan untuk dilakukan berkali-kali. Sebenarnya, apakah itu arti 'kesempatan'? Apakah itu makna 'keputusan'? Bagaimana mungkin kita terkadang menyesal karena sebuah 'keputusan' atas sepucuk 'kesempatan'? Sebenarnya, siapakah yang selalu pantas kita sayangi?

Tere Liye melalui Novel Sunset bersama Rosie memberikan pelajaran yang begitu berharga yaitu, sekuat apapun kita berusaha melupakan masa lalu, masa lalu itu akan semakin lekat di benak kita. Kita hanya boleh "berdamai" dengan masa lalu bukan melupakan. Berdamai untuk memetik hikmah kejadian masa lalu sebagai pelajaran berharga di masa yang akan datang.

Novel karya Tere Liye ini bercerita tentang seorang Tegar yang terjebak dalam situasi dan pilihan yang sangat sulit. Situasi yang dia hadapi mengharuskan dia memilih antara masa lalu atau masa depan. Kepada siapa dia akan melabuhkan cintanya. Apakah Rosie, sahabat Tegar dari kecil yang lebih memilih Nathan sebagai pasangan hidupnya atau Sekar, seorang gadis yang sangat mencintai Tegar dan sabar menunggunya.

Patah hati, hancurlah hati Tegar ketika dia tahu bahwa Rosie menerima cinta Nathan yang baru dua bulan mengenal Rosie tepat disaat mereka di puncak gunung Rinjani. Tegarlah yang mengenalkan Nathan pada Rosie. Nathan adalah sahabat terbaik Tegar sejak SD. Semenjak kejadian di gunung rinjani itu, Tegar tidak pernah lagi muncul dihadapan mereka berdua. Dia menghilang bak ditelan bumi. Tak ada kabar tentang keberadaan Tegar. Hingga akhirnya selepas Rosie dan Nathan wisuda, mereka menikah.

Tegar mulai bisa berdamai dengan hatinya dan seketika rasa sakit yang dulu dia 
rasakan hilang disaat dia melihat dua putri Rosie, Anggrek dan Sakura datang ke apartemen Tegar dan memanggilnya Om. Tegar juga telah memutuskan untuk menerima Sekar dalam hidupnya dan berencana untuk bertunangan.

Tapi itu semua hancur berantakan hanya dalam hitungan detik saja. Kejadian bom di Jimbaran yang telah merenggut nyawa Nathan adalah pangkal dari masalah yang harus dihadapi Tegar. Akibat kejadian itu, Tegar akhirnya membatalkan pertunangannya dengan Sekar dan terbang ke Jimbaran untuk memastikan keadaan keluarga Rosie.

Rosie depresi dan harus dirawat di shelter dan meninggalkan empat anaknya. Anggrek, Sakura, Jasmine, dan juga Lili yang masih berumur satu tahun. Tegar yang hanya satusatunya kerabat Rosie selain Oma memutuskan untuk menjaga dan merawat keempat kuntum Rosie.

Dua tahun Rosie dirawat di Shelter, dan selama itu pula Tegar tidak pernah menghubungi Sekar. Hingga suatu saat, ketika Rosie sembuh dan berkumpul bersama anak- anaknya, Tegar mendapat kabar dari Linda, mantan sekertarisnya di Jakarta yang mengabarkan bahwa Sekar akan bertunangan dengan laki-laki yang tidak dia cintai. Mendengar kabar tersebut Tegar langsung mendatangi rumah Sekar dan meminta Sekar untuk memberinya kesempatan sekali lagi.

Sekar membatalkan pertunangannya dan memilih Tegar. Sekar sudah membuat kesempatan dengan tangannya sendiri. Sekarang tinggal Tegar yang berperan. Tegar memutuskan untuk menikahi Sekar. Dia harus memikirkan cara untuk berbicara kepada anak-anak Rosie bahwa Paman terhebat dan keren mereka tidak bisa tinggal bersama mereka di Gili Trawangan.

Disaat inilah Oma berbicara, Oma menceritakan kejadian masa lalu yang tidak diketahui Tegar. Pernikahan Rosie dan Nathan sempat ditunda enam bulan karena menunggu Tegar. Rosie mencintai Tegar. Keputusan sudah Tegar ambil, dia tetap memutuskan untuk menikahi Sekar, gadis yang sangat mencintainya dan dia juga mencintai gadis itu. Meskipun Tegar masih mencintai Rosie dan anak-anaknya tapi itu dengan pengertian cinta yang berbeda.

Tibalah di acara pernikahan Tegar dan Sekar, disaat mereka berdua sedang melangkah bergandengan tangan ke tengah ruangan, disaat itu pula Lili anak terkecil Rosie berlari dan memeluk kaki Tegar. Dia akhirnya berbicara setelah 2 tahun dia enggan berbicara dengan siapapun kecuali dengan Jasmin. Kata-kata Lili lah yang akhirnya membuat Sekar meminta Tegar untuk menikahi Rosie.

\section{Antisipasi dan Retrospeksi}

Novel Sunset Bersama Rosie ending ceritanya tidak sesuai dengan harapan pembaca, dalam hal ini saya sendiri. Setelah membaca novel ini, justru membuat saya berandai-andai . Hal tersebut dikarenakan alur cerita yang tidak sesuai dengan keinginan pembaca, khususnya saya sendiri. Banyak pertanyaan yang muncul ketika selesai membaca novel ini. Pertanyaan pertama, mengapa akhir cerita ini Tegar justru menikah dengan Rosie? Harapan saya Tegar lebih baik menikah dengan Sekar. Kalau saja Oma tidak menceritakan perasaan Rosie kepada Tegar mungkin Tegar akan menikah dengan Sekar.

"Berjanjilah tegar, apa pun yang kau dengar malam ini, kau akan tetap kembali ke Jakarta. Karena kau menitipkan kesempatanmu pada guratan takdir, maka setelah kau mendengar sepotong kejadian masa lalu itu kau juga tetap akan menitipkan kesempatan itu pada guratan takdir. Jika mawar itu akhirnya tumbuh di tegarnya karang, maka biarlah kuasa Tuhan membuktikannya." (SBR, 2011: 412).

Pengandaian yang kedua, kalau saja Nathan mendengarkan saran dari Tegar dan membatalkan pergi ke pantai Jimbaran, maka 
tidak akan ada tragedi di Jimbaran. "Bukankah itu angka sial? Seharusnya kau tidak perlu mengadakan acara spesial." (SBR, 2011:3). Dapat dipastikan pula keluarga Nathan dan Rosie menjadi keluarga yang paling bahagia. Nathan benar, keluarga mereka bahagia. Tiga belas tahun pernikahan dengan intensitas kebahagiaan tinggi, tanpa henti bagai air di kaki pegunungan yang memancar deras. (SBR, 2011:3). Namun, Jimbaran, malam itu sungguh mengambil semua kebahagiaan keluarga Rosie.

"Sepuluh tangkai mawar biru itu terlepas dari tangan Jasmine. Berhamburan. Menyusul suara ledakan kencang itu, asap hitam mengepul tiga meja dari mereka. Dengan kekuatan massa kali kecepatan cahaya dikuadratkan bom itu meledak. Partikel-partikel atom bertabrakan. Bertabrakkan lagi. Lagi. Dan lagi. Partikel itu kecil saja. Tetapi karena tabrakan itu terjadi beruntun jutaan kali, dengan kecepatan memedihkan mata, maka ledakan yang dihasilkan sungguh memancarkan aura kematian mengerikan. Menghajar apa saja yang ada di sekitarnya." (SBR, 2011:21).

Namun, walau bagaimana pun itu kehendak penulis untuk menentukan alur ceritanya.

\section{Kesan Keserupaan dalam Kehidupan}

Dalam novel Sunset Bersama Rosie banyak hal yang diceritakan dalam novel tersebut yang mungkin juga sebagian orang pernah mengalaminya, tidak terkecuali juga dengan saya. Novel ini menceritakan tentang cinta, perasaan, kerinduan, kebencian, dan rasa sakit yang semuanya itu ada dalam diri manusia. Cinta, setiap orang pasti memiliki rasa cinta begitu juga Tegar. Namun, ada sebagian orang yang dengan mudah mengutarakan perasaan itu dan sebagian orang justru lebih memilih memendamnya. Tegar mencintai Rosie dan selama 20 tahun
Tegar menyimpan perasaan itu, namun ketika perasaan itu akan diungkapkan kepada Rosie, justru didahului oleh sahabatnya, Nathan.

"Dua puluh tahun lamanya aku memendam rasa itu, merasa waktu untuk mengatakannya tidak pernah sempurna. Menunggu. Dua puluh tahun menabur pelan-pelan seтиa benih. Kebersamaan yang menyenangkan. Bukankah di mana ada Rosie di situ ada aku, dan sebaliknya, di mana ada aku di situ ada Rosie." (SBR, 2011:35).

Memendam perasaan tidak hanya dialami oleh Tegar. Banyak sekali orang yang tidak berani mengungkapkan apa yang dirasakannya dan lebih memilih untuk memendam perasaan itu, termasuk juga saya. Banyak pepatah yang menyatakan bahwa memendam perasaan akan jauh lebih menyakitkan daripada sebuah penolakan. Mungkin pepatah tersebut ada benarnya juga, tapi bagi saya dan sebagian orang akan sulit untuk melakukannya. Banyak hal yang membuat seseorang lebih memilih untuk memendam perasaan begitu juga Tegar. Tegar selama 20 tahun menunggu waktu yang tepat untuk mengutarakan perasaannya yang justru keputusannya itu membuatnya menyesal tidak mengungkapkannya dari dulu. Penyesalan memang selalu datang di belakang. Begitulah kehidupan. Selain itu, ketika patah hati pun sebagian orang akan melakukan hal yang sama seperti yang dilakukan oleh tegar.

"Setiap jengkal sepanjang hari berusaha melupakan Rosie. Membuang foto-foto kami ke kotak sampah. Percuma. Aku tidak akan pernah bisa melupakannya. Malamnya malah panik berusaha mengais-ngais kotak sampah. Berharap menemukan foto yang terlanjur kubuang. Lantas terduduk saat menyadari foto itu telah pergi dibawa truk sampah keliling. Menyesali." (SBR, 2011:166). 
Apa yang dilakukan oleh Tegar merupakan hal yang wajar dilakukan ketika patah hati. Aneh memang, tetapi begitulah kenyataannya. Ketika ingin melupakannya kita pun ingin membuang semua hal yang ada hubungannya dengan orang tersebut, tetapi setalah itu justru kita menyesalinya.

Namun, novel Sunset Bersama Rosie banyak memberikan pelajaran yang begitu berharga, bahwa sekuat apa pun kita berusaha melupakan masa lalu, masa lalu itu akan semakin lekat di benak kita.

"Setiap jengkal sepanjang haari berusaha mengusir bayangan wajah Rosie. Maka setiap jengkal pula bayangan wajahnya memenuhi langit-langit kontrakanku. Tidak. Aku tidak akan pernah bisa melupakannya. Seharusnya aku berdamai dengan semua...Sungguh menyenangkan merasakan itu seтua. Berdamai dengan masa lalu yang menyakitkan. Berdamai dengan masa lalu bukan melupakan." (SBR, 2011:167).

Berdamai dengan masa lalu bukan melupakan. Berdamai itu kata yang mudah untuk diucapkan tapi menyakitkan untuk dilakukan. Sikap Tegar yang bisa berdamai dengan masa lalu bukan melupkannya patut ditiru, walaupun itu tidak mudah dilakukan. Di sini kita belajar betapa indahnya memaafkan kesalahan orang lain. Meski tidak mudah, meski begitu sulit, kebesaran dan kelapangan jiwa adalah salah satu jalan untuk kembali hidup dengan kebahagiaan.

Selain itu, novel ini juga memberikan pelajaran tentang apa itu kesempatan. Sebagian orang bahkan mungkin saya sering mengatakan tidak ada kesempatan, padahal bukan tidak ada kesempatan tetapi kita sendiri yang harus berani membuat kesempatan.

"Kau terlampaui mencintai Rosie, Tegar. Maka hatimu terkadang menipu. Kau dulu sering bertanya apakah kau punya kesempatan? Menurut orang tua ini, kalian berdualah yang justru yang justru tidak pernah berani membuat kesempatan itu. Betapa tidak beruntungnya . kalian menyerahkan sepenuhnya kesempatan itu kepada suratan nasib..." (SBR, 2011:409).

Pesan yang didapatkan dari kutipan tersebut yaitu bahwa kita harus berani mengutarakan atau menyampaikan perasaan yang kita miliki apapun resikonya. Selain itu, novel ini juga mengingatkan saya, bahwasanya sesuatu yang berlebihan itu tidak baik. Begitu juga dalam hal cinta. Apakah dunia memang begitu? Kita tidak akan pernah mendapatkan sesuatu jika kita terlalu menginginkannya. Kita tidak akan pernah mengerti hakikat memiliki, jika kita terlalu ingin memilikinya. (SBR, 2011:403). Kadang hidup memang begitu, ada yang mencintai kita dengan tulus namun kita mencintai seseorang yang justru orang tersebut mencintai orang lain. Terkadang hidup tidak sesuai dengan yang kita harapkan. Untuk itu kita tidak boleh terlalu ingin memiliki sesuatu karena kalau tidak tercapai terasa akan lebih menyakitkan.

Hal lain yang dapat diambil pelajaran dalam novel ini yaitu karakter dari Sekar yang sangat sabar dalam menunggu Tegar dan setelah kesabarannya membuahkan hasil, Sekar justru harus mengikhlaskan Tegar untuk Rosie. "Menikahlah dengan Rosie, Tegar. Menikahlah. Pagi ini aku paham, aku mengerti, kalian ditakdirkan bersama sejak kecil. Aku sungguh akan belajar bahagia menerimanya, dan itu akan lebih mudah dengan pemahaman yang baru. Aku akan baik-baik saja. Menikahlah!" (SBR,2011: 425). Setelah membaca novel saya harus lebih banyak belajar untuk bisa ikhlas seperti Sekar walaupun itu sulit, bahwa cinta itu tidak harus memiliki. Kalau seseorang berada di posisi Sekar mungkin jarang yang akan mengambil keputusan tersebut. Di sini kita akan mengerti makna cinta dengan pemahaman yang berbeda.

Penggambaran watak tokoh 4 kuntum bunga (Anggrek, Sakura, Jasmine, 
Lili), anak-anak dari pernikahan Rosie dan Nathan, menurut saya sedikit kurang nuansa kekanak-kanakkan. Dialog dan sikap yang ditunjukkan mereka terlalu dewasa dibandingkan anak-anak seusia mereka. Namun demikian, dari kebijakan-kebijakan 4 kuntum bunga Rosie inilah saya belajar.

Balajar memaafkan orang lain, belajar berdamai dengan sesuatu yang pahit, belajar untuk tetap menjalani kehidupan sepahit apapun. “Om tunggu! TUNGGU!” Jasmine dengan suara bergetar berseru. Enam petugas menghentikan langkah. Membalik badan. Jasmine mendekat. Persis berdiri di depan tervonis hukuman mati. Mata itu berdenting menahan tangis. $\mathrm{Ya}$ Tuhan, gadis kecil itu sungguh menahan tangisnya. Dan ia gemetar mengulurkan setangkai mawar biru itu.

"Kata Paman Tegar...., kata Paman Tegar, kami tidak boleh membenci Om, tadi pagi Paman Tegar bilang, kami tidak boleh seddikitpun membenci Om. Meski, meski..." (SBR, 2011: 244).

Momen inilah yang membuat saya mengerti apa sebenarnya isi dari keseluruhan cerita dalam buku ini. Penerimaan, pengikhlasan, memaafkan, semuanya terangkum dalam kejadian itu. Bahkan, saya sempat meneteskan air mata haru terhadap apa yang dilakukan Jasmine karena ia bersedia memaafkan pelaku pemboman yang menjadi penyebab kematian Ayah mereka.

\section{Respon Personal}

Novel Sunset Bersama Rosie dalam bayangan saya adalah kisah Rosie seperti yang tertera pada cover. Ternyata isi keseluruhan novel lebih menceritakan tentang perjuangan seorang Tegar. Dalam novel sosok Tegar begitu terlihat sangat sempurna. Penggambarannya sebagai sosok yang hebat, keren, istimewa, bijak dan serba bisa.
"Seandainya, Jasmine punya empat paman seperti Paman Tegar, maka Jasmine tidak perlu menunggu hingga larut malam untuk mendengar Paman bercerita." (Sunset Bersama Rosie, 2011: 5).

"Kau sungguh paman paling hebat, keren, dan super bagi mereka." Rosie menyeka ujung matanya yang basah. (Sunset Bersama Rosie, 2011: 250).

"Anak-anak selalu selalu suka kalau aku yang memegang kemudi. Apalagi Sakura. Mereka anak-anak yang periang. Mana pernah takut dengan kecepatan. Semakin cepat kapal cepat itu membelah lautan, semakin senang mereka berseru-seru. Soal mengemudikan kapal dengan keren tak ada yang bisa mengalahkan paman Tegar. Paman Tegar mereka memang pernah menang lomba jetski di Bali. Aku tersenyum bangga." (Sunset Bersama Rosie, 2011: 99).

"kau mungkin tidak pernah mendapatkan pendidikan psikolog, Tegar. Kau mungkiin tak berbakat menjadi psikiater." Ayasa tertawa kecil bergurau. "tetapi kau dokter terbaik bagi anak-anak itu, Tegar. Kau adalah paman paling hebat, kerena dn super bagi mereka. Kalau ada orang yang bisa membawa anakanak itu melewati masa-masa sulit ini, maka kaulah orangnya." (Sunset Bersama Rosie, 2011: 143).

"Setahun berlalu perusahaan sekuritas ternama itu terpesona dengan pekerjaanku. Amat terpesona. Karirku melesat bagai komet, terangbenderang. Siapa yang tidak mengenal Tegar Karang? Junior associate yang bagai kesetanan bekerja. Mengambil banyak inisiatif, tidak lelah dengan seluruh rangkaian diskusi, prestasi, dan eksekusi. Maka 
dengan mudah, titik-titik karir $k u$ lampaui. Kecintanku mendaki gunung memberiku fisik yang prima." (Sunset Bersama Rosie, 2011: 69-70).

Namun, saya justru menilai Tegar sebagai orang yang tidak berani mengambil keputusan. "Kau tidak akan membatalkan pernikahan dengan Sekar, bukan?" Oma bertanya prihatin, matanya redup menatap. "Aku tidak tahu, tepatnya belum tahu." (SBR, 2011:70). Selain itu, Tegar juga suka mengumbar janji atau pemberi harapan palsu. Tegar berjanji tidak akan membuat Sekar menangis. "Berjanjilah kau tidak akan membuat gadis itu menangis." Aku mengangguk. Suara nyanyian Putri Duyung terdengar indah. (SBR, 2011:172). Namun, Tegar membuat Sekar menangis untuk kesekian kalinya. Senyap. Tangisan pelan Sekar menjadi lagu sendu pengantar sunset. Empat puluh tujuh detik berlalu. Matahari sempurna tenggelam. Aku menghela napas. Maafkan aku Oma, Sekar menangis. (SBR, 2011:179). Tegar juga berjanji akan segera pulang ke Jakarta untuk melangsungkan pertunanngan yang batal.

"Tentu saja, Sekar. Tentu, aku akan segera kembali ke jakarta setelah semua urusan ini selesai. Aku langsung datang ke rumahmu. Jadi bilang papa-mama, terus saja bersiap selama seminggu ini, calon menantunya akan datang kapan saja, mungkin sambil terjun-payung dari pesawat." Aku mencoba balas bergurau, tertawa." (SBR, 2011:53).

Namun, Tegar tak kunjung memenuhi janjinya tersebut. Tegar juga kemudian membuat janji lagi dalam waktu satu minggu akan bertunangan dengan Sekar. "Beri aku satu minggu, Sekar. Aku juga akan menjadi tunangan yang hebat, keren, dan super untukmu." (SBR, 2011: 102). Satu minggu pun berlalu, Tegar belum juga menunaikan janjinya. "Aku sepertinya tidak akan bisa pulang ke Jakarta minggu depan.
Minggu depannya juga tidak. Aku cemas aku tidak bisa pulang bulan-bulan ini. Aku tidak tega meninggalkan anak-anak. Mereka tidak punya siapa-siapa selain aku." (SBR, 2011:177). Selain itu tegar juga saya nilai sebagai orang yang plin-plan, tidak teguh pendirian.

"Apa yang telah kulakukan di Gili Trawangan? Oma jangan-jangan benar, aku terlalu mencintai anakanak. Aku melupakan sepotong janji kehidupanku bersama Sekar. Oma benar, jangan-jangan aku kembali menyulam harapan itu. Padahal, apalagi yang ingin kulakukan setelah Rosie sembuh? Anak-anak sudah mendapatkan ibunya. Tugasku sudah selesai. Apa aku menginginkan hal lain? Menginginkan kesempatan itu?"

Tegar menurut saya plin-plan karena Tegar awalnya mencintai Rosie bahkan terlalu mencintainya. "Rosie, aku mencintaimu. Aku tidak pernah mengerti perasaan itu, tetapi aku mencintaimu sejak kau masih berkepang dua. Sejak kita masih cemong air sawah. Mengejar capung. Menangkapi kodok hijau meski kau jijik sekali." (SBR, 2011: 31). Namun, setelah Rosie akan menikah dengan Nathan, Tegar berusaha melupakan Rosie.

"Aku harus segera menyibukkan diri. Membunuh dengan tega setiap kali kerinduan itu muncul. Berat sekali melakukannya, karena itu berarti aku harus menikam hatiku setiap detik. Wajah Rosie selalu datang menggangguku. Aku bisa mengukir wajahnya di langit-langit kamar. Menatap wajahnya di bening bak air mandi. Di piring kosong. Apa yang bisa kulakukan? Hingga kapan semua ini akan berakhir. Hingga kapan aku bisa melupakannya. Berdamai.” (SBR, 2011:68).

Seiring waktu berjalan, Tegar sudah bisa berdamai dengan masa lalunya dan 
berusaha mencitai Sekar. Di tahun ketiga pertemanan kami, aku memutuskan mencintainya. Gadis itu sempurna bagiku. Dan aku bisa belajar mencintainya. Dengan pengertian cinta yang baru (SBR, 2011: 52). Aku mencintai sekar, dan aku tidak berbohong. Aku tahu ada banyak yang berubah dari caraku memahami kesendirian hidup. Tetapi setipis apa pun perasaan itu, aku mencintainya. (SBR, 2011:179). Bahkan Tegar memutuskan untuk bertunangan dengan Sekar.

"Di tahun ke empat, sekar memintaku memberikan komitmen hubungan jangka panjang. Tanpa lelah. Sepanjang tahun. "Akhirnya, cintaku yang teramat besar kepadamu bisa mengalahkan cintamu yang teramat besar kepada Rosie." Sekar tertawa, tersipu saat aku akahirnya bisa bilang iya dengan lega untuk acara pertunangan kami.', (SBR, 2011: 52).

Namun, setelah berkomitmen untuk hubungan yang lebih serius, Tegar malah ingin mendapatkan kesempatannya kembali yang sempat tertunda untuk bisa memiliki Rosie. Dan semua itu menyesakkan, lebih tepatnya memunculkan kekhawatiran. Jangan-jangan aku berharap memiliki kesempatan kedua? Jangan-jangan perasaan itu kembali mekar seperti lima belas tahun silam.(SBR, 2011: 209).

Selain memberikan harapan kepada Sekar, Tegar juga memberikan harapan kepada Rosie. Kembalilah ke Jakarta, Tegar. Sekar menunggumu. Tidak ada lagi yang tersisa di sini. Rosie menatap redup, berkata-kata lewat matanya yang sembab. Aku menggeleng lagi. Tidak. Aku akan menemanimu melewati semua kesedihan ini (SBR, 2011:54). Rosie pun diam-diam menyukai Tegar. Oma berseru lirih, "Rosie mencintaimu, Tegar. Rosie selalu mencintai kau. Sejak kecil. Masalahnya, cinta kau yang terlalu besar tidak pernah memberikannya kesempatan untuk mengerti. Tetapi dia selalu dan akan selalu mencintaimu."(SBR,
2011:414). Namun, ketika Rosie sudah mulai membuka hati untuk Tegar, disaat itu pula Tegar ingin menjalin hubungan kembali dengan Sekar dan ingin menikahinya setelah mengetahui bahwa Sekar akan menikah dengan laki-laki lain. "Mas Tegar, Sekar memutuskan, Sekar memutuskan menikah dengan lelaki itu. Besok pagi Sekar akan bertunangan, minggu depan mereka segera menikah.” (SBR, 2011: 334).

Baiklah, "Aku akan menikah dengan Sekar, Ros."

"Aku akan menikahinya minggu depan, Ros. Percaya atau tidak, pernikahan itu akan dilangsungkan di tempat yang sama. Tempat yang dua tahun lalu kami rencanakan. Konsep acara yang sama, bahkan dengan gaun yang sama." Aku tertawa kecil." (SBR, 2011:388). Tetapi pada akhirnya, Tegar justru menikah dengan Rosie.

"Sekar menahan tangis, tubuhnya bergetar, satu tangannya yang lain meraih lenganku, menatapku, "Menikahlah dengan Rosie, Tegar. Menikahlah. Pagi ini aku paham, aku mengerti, kalian ditakdirkan bersama sejak kecil. Aku sungguh akan belajar bahagia menerimanya, dan itu akan lebih mudah dengan pemahaman yang baru. Aku akan baik-baik saja. Menikahlah!" (SBR,2011: 425).

Berdasarkan kutipan-kutipan tersebut, tampak bahwa Tegar itu banyak mengumbar janji dan juga tidak teguh pendirian. Namun, saya justru kagum dengan tokoh sampingan yaitu Sekar yang digambarkan sebagai tokoh yang baik hati yang mungkin jarang kita temui di zaman sekarang ini dengan mengikhlaskan kekasihnya menikah dengan orang lain. Sekar berani mengambil keputusan walaupun hal tersebut akan melukai hatinya sendiri. Tetapi, itulah cinta. Novel ini mengajarkan saya bahwasanya cinta dengan hakikat ingin memiliki itu berbeda karena cinta tidak selalu harus memiliki. 


\section{PENUTUP}

Novel-novel Tere Liye dari awal mulai terbitnya selalu mendapat tanggapan atau resepsi begitu juga novel Sunset Bersama Rosie. Tanggapan atau resepsi itu berupa penilaian dengan kriteria estetika maupun ekstra estetik. Sebagian pembaca ada yang merespon secara positif dan ada juga sebagian orang lain yang merespon secara negatif. Hal tersebut disebabkan oleh perbedaan cakrawala harapan setiap pembaca, karena masing-masing pembaca mempunyai pengalaman, pengetahuan yang berbeda-beda. Namun, secara keseluruhan novel "Sunset Bersama Rosie" karya Tere Liye masih relevan dengan realitas kehidupan masyarakat di Indonesia. Dengan demikian, berdasarkan respon saya setelah membaca novel Sunset Bersama Rosie ini secara keseluruhan novel ini merupakan novel yang memiliki nilai.

\section{E. DAFTAR PUSTAKA}

Kleden, I. 2004. Sastra indonesia dalam Enam Pertanyaan Esai-esai Satra dan Budaya. Jakarta: Pustaka Utama Grafiti.

Liye, Tere. 2011. Sunset Bersama Rosie. Jakarta: Mahaka.

Pradopo, R. D. 2002. Kritik Sastra Indonesia Modern. Jakarta: Gama Media.

Pradopo, R. D. 2011. Beberapa Teori Satra, Metode Kritik, dan Penerapannya. Yogyakarta: Pustaka Pelajar.

Siswanto, W. 2008. Pengantar Teori Sastra. Jakarta: Grasindo.

Susanto, D. 2012. Pengantar Teori Sastra. Yogyakarta: Caps. 